\title{
Determination of Employee Competency, Work Discipline and Service Quality to Visitor Loyalty with Visitors Satisfaction as Intervening Variables in Library Areas in Bintan Regency
}

\author{
Imalinda Deryane Fachruddin Bambang Satriawan Sri Yanti \\ Faculty of Economics, Batam University, Riau Islands, Indonesia
}

\begin{abstract}
The library has a major contribution in building an educated society. Knowledgeable society can be a strong social foundation to drive the process of community transformation towards a more advanced life. There are several factors that must be improved, such as employee competency, employee discipline, as well as service quality. These things are expected to increase library visitor satisfaction which affects visitor loyalty. Calculation of the path coefficient in this study is assisted by Smart PLS Ver 3.0. The results of the study are as follows: The effect of variable $\mathrm{X} 1$ on $\mathrm{Y} 1$ has a $\mathrm{p}$ value $(0.075)>0.05$, so the acquisition of these results shows that X1 does not have a significant determination of $Y 1$. The effect of variable $X 1$ on $Y 2$ has a $p$ value $(0.008)<0.05$, so the acquisition of these results shows that X1 has a significant determination of Y2. The effect of variable X2 on Y1 has a p value $(0.144)>0.05$, so the acquisition of these results shows that $\mathrm{X} 2$ does not have a significant determination of $\mathrm{Y} 1$. The effect of variable X2 on $\mathrm{Y} 2$ has a $\mathrm{p}$ value $(0.725)>0.05$, so the acquisition of these results shows that X2 does not have a significant determination of $\mathrm{Y} 2$. The effect of variable $\mathrm{X} 3$ on $\mathrm{Y} 1$ has a $\mathrm{p}$ value $(0.010)<0.05$, so the acquisition of these results shows that $\mathrm{X} 3$ has a significant determination of $\mathrm{Y} 1$. The influence of variable $\mathrm{X} 3$ on $Y 2$ has a $p$ value $(0.032)<0.05$, the acquisition of these results shows that $X 3$ has a significant determination of $\mathrm{Y} 2$. The effect of the variable $\mathrm{Y} 1$ on $\mathrm{Y} 2$ has a $\mathrm{p}$ value $(0,000)<0.05$, then $\mathrm{Y} 1$ has a significant determination of $\mathrm{Y} 2$.
\end{abstract}

Keywords: employee competence, work discipline, quality of service, customer satisfaction and customer loyalty DOI: $10.7176 / \mathrm{EJBM} / 12-21-09$

Publication date:July $31^{\text {st }} 2020$

\section{Introduction}

Republic of Indonesia Law No. 43 of 2007 concerning the library CHAPTER I article 1 paragraph (1) states that: a library is an institution or institution that manages the collection of written works, printed works, and / or records of educational needs, research, preservation, information, and recreation of the visitors. With the existing regulatory basis, the library is an institution or institution that manages information that is included as well as not digital (digital) which must be managed by professionals who are useful for the needs of users. Paragraph (9) So the definition of visitors is individuals, groups of people, communities or institutions that utilize library service facilities. From this information it can be interpreted that anyone who uses library services is called a user.

Library visitors visit to the library is carried out continuously regardless of the amount and time. That is, every time there is a need to search for information and a collection of books always go to the library. This means that the commitment of library customers in establishing relationships with the library last deeply and consistently in the future and recommending to other friends to use the library services is a manifestation of customer loyalty (Jasfar 2012)

Customer satisfaction is a comparison between the customer's perception of the service received and his expectation before using the service (Zeithaml and Bitner in (Jasfar 2012)). Quality of service or service centered on efforts to meet the needs and desires of customers and the provision of delivery to offset customer expectations. On the quality of service, of course, every person or an organization and institution requires competence related to what will be provided in providing the best quality of service to consumers or customers so that they can feel their own satisfaction (Hermawati 2018).

Competencies possessed by employees will certainly have an impact on what will be received by service users, of course, many views about the competency itself. According to (Wibowo 2012) states that competence is an ability to carry out or carry out a job or task based on skills and knowledge and is supported by the work attitude demanded by the job. Competence is an expertise or understanding of someone with reflected from the skills and knowledge of job responsibilities in work. Of course, from this view then gives an illustration that competence can provide customer satisfaction. The competence of each individual employee and employee, it is important to be one of the supports in providing satisfaction to customers. (Hermawati 2018)Competence and quality are not only part of the measure that customer satisfaction can achieve, some research also looks at how employees work discipline problems or employees in providing services to customers. Work discipline is one of the concerns of customers when getting services from a company engaged in services, because work discipline can reflect one of the professional qualities of someone in carrying out their work. 
According to (Rivai, V dan Sagala 2013) work discipline is a tool used by managers to communicate with employees so that they are willing to change a behavior and to increase awareness as well as someone's willingness to comply with all applicable social norms and regulations in a company. (Hermawati 2018) Work discipline is an awareness and willingness of someone to obey the rules that apply by looking at existing social norms and to make changes in behavior in every job encountered. Hence, a good work discipline will have an impact on improvements that lead to a good satisfaction that is self-satisfaction, organizational satisfaction and satisfaction of people who receive services in a company / agency engaged in services.

\subsection{Formulation of the problem}

Based on the above background, the research problem formulation was determined:

1. Is there a direct determination of Employee Competency in Visitor Satisfaction in the Bintan Regency Regional Library?

2. Is there a direct determination of Employee Discipline on Visitor Satisfaction in the Regional Library of Bintan Regency?

3. Is there a direct determination of Service Quality on Visitor Satisfaction in the Regional Library of Bintan Regency?

4. Is there a direct determination of Visitor Satisfaction of Visitor Loyalty in the Bintan Regency Regional Library?

5. Is there an indirect determination of Employee Competency through Visitor Satisfaction of Visitor Loyalty in the Bintan Regency Regional Library?

6. Is there an indirect determination of Employee Discipline through Visitor Satisfaction of Visitor Loyalty in the Bintan District Regional Library?

7. Is there an indirect determination of Service Quality through Visitor Satisfaction of Visitor Loyalty in the Bintan Regency Regional Library?

\section{Theoretical Basis}

\subsection{Employee Competency}

Theory According to Boulter, Dalziel and Hill (Sutrisno 2009) competence is a basic characteristic of a person that allows him to provide superior performance in certain jobs, roles, or situations. Meanwhile according to (Wibowo 2014) explains competency is an ability to carry out or do a job or task based on skills and knowledge and is supported by the work attitude demanded by the job. Competency also shows the characteristics of knowledge and skills possessed or needed by in every individual who enables them to carry out their duties and responsibilities effectively and raise professional quality standards in their work. 13 of 2003 concerning employment explained that work competency is the work ability of every individual which includes aspects of knowledge, skills, and work attitudes that are in accordance with established standards.

\subsection{Theory of Work Discipline}

Discipline is a very important thing for an organization or company to maintain its continuity. Someone's discipline can be seen from the behavior of employees in carrying out their duties. With high discipline an organization can achieve high. According (Sutrisno 2009) said that discipline is an attitude of willingness and willingness to obey and obey the norms of regulations that apply in the surroundings. Good employee discipline will speed up company goals, while declining discipline will become a barrier and slow down the achievement of company goals. (Hasibuan 2012) explains work discipline is the ability of a person to regularly, diligently, continuously by not violating the rules that apply by not breaking the rules that have been set. Thus, it can be concluded that high discipline can be an important factor to achieve organizational goals effectively and efficiently by preventing actions from both individuals and groups.

\subsection{Service Quality Theory}

Simply put, a good quality of service can be interpreted as a service that benefits or satisfies the customer. In other words, good service quality is a service that meets predetermined quality standards. Service that meets quality standards is a service that is in line with the expectations and satisfaction of the customer / community. According to (Tjiptono 2000) service quality is a dynamic situation that is closely related to products, services, human resources, and processes and the environment that can at least meet or even exceed the quality of service expected. Whereas (Bates and Hoffman 1999) as quoted by S(Sukoco and Nilowardono 2009) stated that service quality is the customer's assessment of the service provision process, thus evaluating service quality means evaluating the service production process. Service quality is a very complex discussion because quality assessment service is different from product quality, especially in nature that is not real (intangible) and production and consumption run simultaneously. Thus, the quality of service is how customers respond to the services consumed or felt (Jasfar 2005). 


\subsection{Theory of Visitor Satisfaction (Customers)}

Quality public service is able to provide services as expected by the customer. According to (Kotler and Amstrong 2014) customer satisfaction is a feeling of pleasure or disappointment someone who arises because of comparing the perceived performance of the product (results) against their expectations. From this definition it can be said if the product performance is not in accordance with customer expectations and if expectations are set too low, then the customer will feel dissatisfied and lead to disappointment, if the performance is in line with expectations, the customer will feel satisfied. Meanwhile according to Richard Oliver (Barnes 2003) satisfaction is the customer's response to meeting their needs. That means the assessment of a product / service provides a level of comfort associated with meeting a need, including meeting needs below expectations or meeting needs that exceed customer expectations. From the explanation above shows that customer satisfaction is a form of response to services provided based on customer expectations. Customers can be said to be satisfied with the product / service provided if what the customer's expectations are given has exceeded and even exceeded their expectations.

\subsection{Visitor Theory (Customer) Loyalty}

When a customer (hereinafter referred to as a visitor) is satisfied with the value provided by a product or service, it is likely to be a visitor for a long time. This is where visitor satisfaction becomes a determining factor in attracting visitors to become loyal visitors. According to Oliver (1997) (in (Aung et al. 2013)) visitor loyalty is a strong commitment to making many repeat purchases of selected products or using services consistently in the future. While loyalty according to Oliver (1993) in quotation Valenzuela A. (2006) is a commitment held firm to buy or re-subscribe to a product or service that is consistently liked in the future. From the explanation above, it can be said that in loyalty there are two components The main thing is consistency and repetition. The visitor can be said to be loyal if he makes repeated purchases (in a library called borrowing) the product consistently. In other words, visitors do not stop using the service the first time, but use the service continuously for a long period of time.

\subsection{Theoretical Framework}

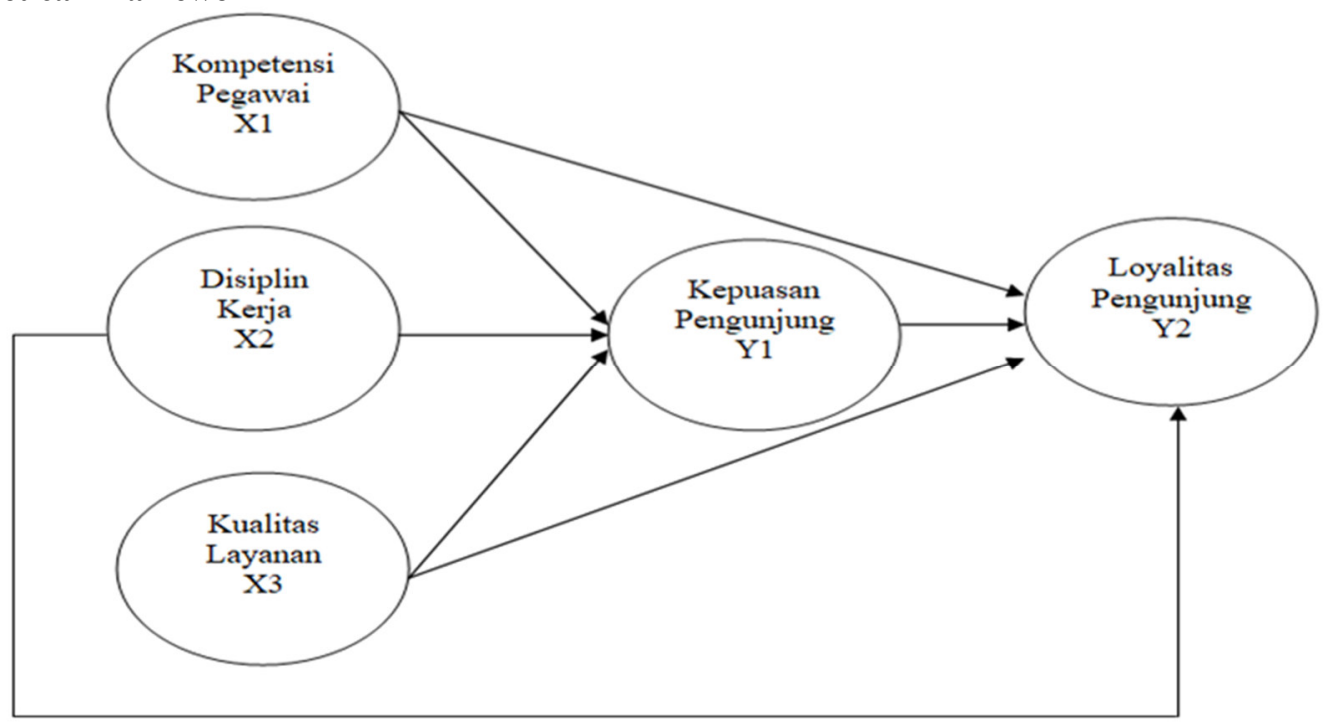

\subsection{Research Hypothesis}

The hypotheses that can be found are as follows:

1. Employee competency has a significant determination of visitor satisfaction.

2. Discipline employees have a significant determination of visitor satisfaction.

3. Service quality has a significant determination of visitor satisfaction.

4. Employee competence has a determination on visitor loyalty.

5. Discipline employees have a significant determination of visitor loyalty.

6. Service quality has a significant determination of visitor loyalty

7. Visitor satisfaction has a significant determination of visitor loyalty.

\section{Research Method}

The location of this research was conducted on the visitors of the Regional Library in the Regency of Bintan.

\subsection{Population}

The population in this study were visitors to the Bintan Regency Regional Library. The size of the population is 
373 people. The data obtained is determined based on the theory that if the population is less than 100 , then it is better to take all, but if the number of subjects is large or more than 100 can be taken between $10-15 \%$ or $10-25 \%$ of the population.

\subsection{Samples}

The determination of the number of research samples determined in this study is based on the calculations put forward by Slovin in Sunyoto (2011:21) as follows:

$$
\mathrm{n}=\frac{\mathrm{N}}{1+\left(\mathrm{n} \mathrm{x} \mathrm{e}^{2}\right)}
$$

Where $\mathrm{n}=$ sample size, $\mathrm{N}=$ population size, $\mathrm{e}=$ the percentage of errors desired or tolerated, which is $10 \%$. Based on the formula, the number of samples taken in this study are:

$$
\mathrm{n}=\frac{\left.273 \times 1^{2}\right)}{1+(373 \times 78,85 \text { which is rounded to } 79}
$$

Then the number of samples to be taken as many as 79 people consisting of Visitors to the District Library of Bintan.

\subsection{Data Collection Techniques}

The data sources used in this study were obtained through:

1. Primary data, namely data obtained directly from respondents by distributing questionnaires in addition to the author also conducted a survey directly to the Bintan Regency Regional Library office where the authors conducted research.

2. Secondary data, i.e. data obtained by conducting library studies relating to the problem to be further examined. Secondary data obtained from references such as books, internet, journals and other sources that can support this research. From the book obtained theories about Employee Competency (X1), Work Discipline (X2), Service Quality (X3), Visitor Satisfaction (Y1), and Visitor Loyalty (Y2).

\subsection{Research Variables}

This research was conducted using three exogenous variables, namely employee competency (X1), work discipline (X2) service quality (X3) one intervening variable namely visitor satisfaction (Y), and one endogenous variable visitor loyalty $(Z)$ e) Data Analysis Techniques The analysis technique in this study uses the PLS technique which is carried out in two stages, namely: 1 . The first step is to test the measurement model, which is to test the validity and reliability of the constructs of each indicator. 2. The second stage is to conduct a structural test model that aims to determine whether there is influence between variables / correlation between constructs measured using the $t$ test of the PLS itself.

\section{Result and Discussion}

Table 1. Validity Test

\begin{tabular}{|c|c|c|c|c|c|}
\hline & X1 & X2 & X3 & X4 & Y \\
\hline X1.1 & $\mathbf{0 , 8 5 5}$ & & & & \\
\hline X1.2 & $\mathbf{0 , 8 7 0}$ & & & & \\
\hline X1.3 & $\mathbf{0 , 8 2 8}$ & & & & \\
\hline X1.4 & $\mathbf{0 , 9 2 4}$ & & & & \\
\hline X1.5 & $\mathbf{0 , 9 2 4}$ & & & & \\
\hline X1.6 & $\mathbf{0 , 8 9 6}$ & & & & \\
\hline X2.1 & & $\mathbf{0 , 7 7 6}$ & & & \\
\hline X2.2 & & $\mathbf{0 , 8 6 4}$ & & & \\
\hline X2.3 & & $\mathbf{0 , 8 2 0}$ & & & \\
\hline X2.4 & & $\mathbf{0 , 7 8 4}$ & & & \\
\hline X2.5 & & $\mathbf{0 , 8 9 2}$ & & & \\
\hline X2.6 & & $\mathbf{0 , 8 8 3}$ & & & \\
\hline X3.1 & & & 0,918 & & \\
\hline X3.2 & & & 0,941 & & \\
\hline X3.3 & & & 0,866 & & \\
\hline X3.4 & & & 0,909 & & \\
\hline X3.5 & & & 0,626 & & \\
\hline
\end{tabular}




\begin{tabular}{|c|c|c|c|c|c|}
\hline & X1 & X2 & X3 & X4 & Y \\
\hline X3.6 & & & $\mathbf{0 , 6 2 8}$ & & \\
\hline Y1.1 & & & & $\mathbf{0 , 6 5 6}$ & \\
\hline Y1.2 & & & & $\mathbf{0 , 8 2 9}$ & \\
\hline Y1.3 & & & & $\mathbf{0 , 6 6 4}$ & \\
\hline Y1.4 & & & & $\mathbf{0 , 6 7 7}$ & \\
\hline Y1.6 & & & & $\mathbf{0 , 7 8 5}$ & \\
\hline Y1.7 & & & & $\mathbf{0 , 8 8 9}$ & \\
\hline Y1.8 & & & & $\mathbf{0 , 7 3 3}$ & \\
\hline Y2.1 & & & & $\mathbf{0 , 8 8 2}$ & \\
\hline Y2.2 & & & & & $\mathbf{0 , 6 9 1}$ \\
\hline Y2.3 & & & & & $\mathbf{0 , 8 6 4}$ \\
\hline Y2.4 & & & & & $\mathbf{0 , 7 9 3}$ \\
\hline Y2.5 & & & & & $\mathbf{0 , 8 4 3}$ \\
\hline Y2.6 & & & & & $\mathbf{0 , 6 6 8}$ \\
\hline Y2.7 & & & & & $\mathbf{0 , 5 7 3}$ \\
\hline Y2.8 & & & & & $\mathbf{0 , 7 3 1}$ \\
\hline
\end{tabular}

Table 2. Reliability Test

\begin{tabular}{|c|c|c|c|c|}
\hline & Cronbach's Alpha & rho_A & Composite Reliability & Average Variance Extracted (AVE) \\
\hline X1 & $\mathbf{0 , 9 4 4}$ & $\mathbf{0 , 9 5 2}$ & $\mathbf{0 , 9 5 5}$ & $\mathbf{0 , 7 8 1}$ \\
\hline x2 & $\mathbf{0 , 9 1 4}$ & $\mathbf{0 , 9 1 9}$ & $\mathbf{0 , 9 3 4}$ & $\mathbf{0 , 7 0 2}$ \\
\hline X3 & $\mathbf{0 , 9 0 0}$ & $\mathbf{0 , 9 2 2}$ & $\mathbf{0 , 9 2 6}$ & $\mathbf{0 , 6 8 2}$ \\
\hline Y1 & $\mathbf{0 , 8 9 9}$ & $\mathbf{0 , 9 1 0}$ & $\mathbf{0 , 9 2 0}$ & $\mathbf{0 , 5 9 2}$ \\
\hline Y2 & $\mathbf{0 , 8 7 9}$ & $\mathbf{0 , 8 9 0}$ & $\mathbf{0 , 9 0 6}$ & $\mathbf{0 , 5 4 9}$ \\
\hline
\end{tabular}

After theoretical discussion and research, the results of this study can be described as follows:

Table 3. Direct Influence

\begin{tabular}{|l|c|c|c|c|c|}
\hline & $\begin{array}{c}\text { Original } \\
\text { Sample (O) }\end{array}$ & $\begin{array}{c}\text { Sample Mean } \\
\text { (M) }\end{array}$ & $\begin{array}{c}\text { Standard Deviation } \\
\text { (STDEV) }\end{array}$ & $\begin{array}{c}\mathbf{t} \\
\text { statistics }\end{array}$ & $\begin{array}{c}\mathbf{p} \\
\text { values }\end{array}$ \\
\hline X1 -> Y1 & 0,202 & 0,210 & 0,113 & 1,781 & $\mathbf{0 , 0 7 5}$ \\
\hline X2 -> Y1 & 0,217 & 0,218 & 0,148 & 1,462 & $\mathbf{0 , 1 4 4}$ \\
\hline X3 -> Y1 & 0,398 & 0,396 & 0,153 & 2,601 & $\mathbf{0 , 0 1 0}$ \\
\hline X1 -> Y2 & 0,217 & 0,221 & 0,081 & 2,660 & $\mathbf{0 , 0 0 8}$ \\
\hline X2 -> Y2 & 0,041 & 0,036 & 0,116 & 0,351 & $\mathbf{0 , 7 2 5}$ \\
\hline X3 -> Y2 & 0,288 & 0,303 & 0,134 & 2,145 & $\mathbf{0 , 0 3 2}$ \\
\hline Y1-> Y2 & 0,400 & 0,385 & 0,109 & 3,680 & $\mathbf{0 , 0 0 0}$ \\
\hline
\end{tabular}

1. The first hypothesis tested is the effect of employee competency variables on visitor satisfaction. Based on the test results, obtained a statistical $t$ value $(1.781)<1.96$ and $\mathrm{p}$ value $(0.075)>0.05$, then $\mathrm{H} 0$ is accepted and $\mathrm{H} 1$ is rejected. Obtaining these results shows that employee competencies do not have a significant determination of visitor satisfaction.

2. The second hypothesis tested is the effect of work discipline variables on visitor satisfaction. Based on the test results, obtained a statistical t value $(1.462)<1.96$ and $\mathrm{p}$ value $(0.144)>0.05$, $\mathrm{H} 0$ is accepted and $\mathrm{H} 2$ is rejected. Obtaining these results shows that work discipline does not have a significant determination of visitor satisfaction.

3. The third hypothesis tested is the effect of service quality variables on visitor satisfaction. Based on the test results, obtained a statistical t value (2.601) $>1.96$ and $\mathrm{p}$ value $(0.010)<0.05$, then $\mathrm{H} 0$ is rejected and $\mathrm{H} 3$ is accepted. Obtaining these results shows that the quality of service has a significant determination of visitor satisfaction.

4. The fourth hypothesis tested is the effect of employee competency variables on visitor loyalty. Based on the test results, obtained a statistical $t$ value $(2.660)>1.96$ and $\mathrm{p}$ value $(0.008)<0.05$, then $\mathrm{H} 0$ is rejected and $\mathrm{H} 4$ is accepted. Obtaining these results shows that employee competencies have a significant determination of visitor loyalty.

5. The fifth hypothesis tested is the effect of work discipline variables on visitor loyalty. Based on the test results, obtained a statistical $\mathrm{t}$ value $(0.351)<1.96$ and $\mathrm{p}$ value $(0.725)<0.05$, then $\mathrm{H} 0$ is accepted and $\mathrm{H} 5$ is rejected. Obtaining these results shows that work discipline does not have a significant determination of visitor loyalty.

6. The sixth hypothesis tested is the effect of service quality variables on visitor loyalty. Based on the test results, 
obtained a statistical $\mathrm{t}$ value $(2.145)>1.96$ and $\mathrm{p}$ value $(0.032)<0.05$, then $\mathrm{H} 0$ is rejected and H6 is accepted.

Obtaining these results shows that the quality of service has a significant determination of visitor loyalty.

7. The seventh hypothesis tested is the effect of visitor satisfaction variables on visitor loyalty. Based on the test results, obtained a statistical t value $(3,680)>1.96$ and $\mathrm{p}$ value $(0,000)<0.05$, then $\mathrm{H} 0$ is rejected and $\mathrm{H} 7$ is accepted. Obtaining these results shows that visitor satisfaction has a significant determination of visitor loyalty.

Table 4. indirect influence

\begin{tabular}{|c|c|c|c|c|c|}
\hline & $\begin{array}{c}\text { Original } \\
\text { Sample (O) }\end{array}$ & $\begin{array}{c}\text { Sample Mean } \\
(\mathbf{M})\end{array}$ & $\begin{array}{c}\text { Standard Deviation } \\
\text { (STDEV) }\end{array}$ & $\begin{array}{c}\text { t statistics } \\
(\mid \mathbf{O} / \text { STDEV } \mid)\end{array}$ & $\begin{array}{c}\text { p } \\
\text { values }\end{array}$ \\
\hline X1 -> Y1 -> Y2 & 0,081 & 0,082 & 0,050 & 1,622 & $\mathbf{0 , 1 0 6}$ \\
\hline X2 -> Y1 -> Y2 & 0,087 & 0,084 & 0,063 & 1,373 & $\mathbf{0 , 1 7 0}$ \\
\hline X3 -> Y1 -> Y2 & 0,159 & 0,152 & 0,071 & 2,229 & $\mathbf{0 , 0 2 6}$ \\
\hline
\end{tabular}

8 . Based on the test results, obtained indirect effect with a t value of statistics $(1.622)<1.96$ and $p$ value $(0.106)>$ 0.05 , then the acquisition of these results shows that employee competency indirectly does not have a significant determination of loyalty visitors through visitor satisfaction. In other words it can be concluded that visitor satisfaction does not have a significant determination in mediating the relationship of employee competence to visitor loyalty.

9. In the second indirect effect, obtained the value of $t$ statistic $(1.373)<1.96$ and $p$ value $(0.170)>0.05$, then the results of these results indicate that employee discipline indirectly does not have a significant determination of visitor loyalty through visitor satisfaction. In other words, it can be concluded that visitor satisfaction does not have a significant determination in mediating employee discipline relationships to visitor loyalty.

The third indirect effect is the indirect effect of service quality variables on visitor loyalty through visitor satisfaction as an intervening variable. Based on the test results, the $t$ value of statistics $(2,229)>1.96$ and $p$ value $(0.026)<0.05$, then the results of these results indicate that service quality indirectly has a significant determination of visitor loyalty through visitor satisfaction. In other words, it can be concluded that visitor satisfaction has a significant determination in mediating the relationship of service quality to visitor loyalty.

Table 5. the indirect effect of service quality variables on visitor loyalty through visitor satisfaction as an intervening variable.

\begin{tabular}{|l|l|l|l|l|l|}
\hline \multicolumn{2}{|c|}{ Relationship } & \multicolumn{1}{|c|}{$\begin{array}{c}\text { Coefficient } \\
(\text { Path })\end{array}$} & $\mathrm{t}_{\text {count }}$ & $\mathrm{P}_{\text {value }}$ & $\mathrm{t}_{\text {table }}$ \\
\hline Direct & Employee competence -> visitor loyalty & 0,217 & 2,660 & 0,008 & 1,96 \\
\hline Indirect & $\begin{array}{l}\text { Employee competence -> visitor satisfaction -> } \\
\text { visitor loyalty }\end{array}$ & 0,081 & 1,622 & 0,106 & 1,96 \\
\hline Total Effect & Employee competence -> visitor loyalty & 0,297 & 2,935 & 0,003 & 1,96 \\
\hline Direct & Employee discipline -> visitor loyalty & 0,041 & 0,351 & 0,725 & 1,96 \\
\hline Indirect & $\begin{array}{l}\text { Employee discipline -> visitor satisfaction -> } \\
\text { visitor loyalty }\end{array}$ & 0,087 & 1,373 & 0,170 & 1,96 \\
\hline Total Effect & Employee discipline -> visitor loyalty & 0,128 & 0,935 & 0,350 & 1,96 \\
\hline Direct & Service Quality -> visitor loyalty & 0,288 & 2,145 & 0,032 & 1,96 \\
\hline Indirect & $\begin{array}{l}\text { Service Quality -> visitor satisfaction -> visitor } \\
\text { loyalty }\end{array}$ & 0,159 & 2,229 & 0,026 & 1,96 \\
\hline Total Effect & Service Quality -> visitor loyalty & 0,447 & 3,093 & 0,002 & 1,96 \\
\hline
\end{tabular}

10. Judging from the value of all the path coefficients the total effect is greater than the direct effect, namely competence of $0.297>0.217$, work discipline of $0.128>0.041$, and service quality of $0.447>0.288$. This shows that visitor satisfaction can increase the effect of employee competence, work discipline, and service quality on visitor loyalty.

Tabel 6. $r$ square test

\begin{tabular}{|l|l|l|}
\hline & R Square & R Square Adjusted \\
\hline visitor satisfaction & 0,562 & 0,545 \\
\hline visitor loyalty & 0,707 & 0,691 \\
\hline
\end{tabular}

11. Through the coefficient of determination (R-square) contained in the table above it can be seen that employee competence, employee discipline and service quality have an effect of $56.2 \%$ on visitor satisfaction. Judging from the value of the path coefficient, the most dominant in influencing visitor satisfaction sequentially is the service quality variable with a path coefficient value of $0.398(28.5 \%)$, then employee discipline with a path coefficient of $0.217(14.9 \%)$ and finally employee competence with a path coefficient of $0.202(12.9 \%)$. Then employee competence, work discipline, service quality, and visitor satisfaction influence $70.7 \%$ of visitor loyalty. Judging from the value of the path coefficient, the most dominant in influencing visitor loyalty 
sequentially is the visitor satisfaction variable with a path coefficient of $0.400(30.9 \%)$, then service quality with a path coefficient of $0.288(21.8 \%)$, then employee competence with path coefficient of $0.217(15.2 \%)$ and finally employee discipline with a path coefficient of $0.041(2.9 \%)$

\section{Conclusion}

1. Employee competence does not have a significant determination of visitor satisfaction.

2. Work discipline does not have a significant determination of visitor satisfaction.

3. Service quality has a significant determination of visitor satisfaction.

4. Employee competence has a significant determination of visitor loyalty.

5. Work discipline does not have a significant determination of visitor loyalty.

6. Service quality has a significant determination of visitor loyalty.

7. Visitor satisfaction has a significant determination of visitor loyalty.

8. Visitor satisfaction does not have a significant determination in mediating the relationship between employee competency and visitor loyalty.

9. Visitor satisfaction does not have a significant determination in mediating the employee's disciplinary relationship to visitor loyalty.

10. Service quality indirectly has a significant determination of visitor loyalty through visitor satisfaction. In other words, it can be concluded that visitor satisfaction has a significant determination in mediating the relationship of service quality to visitor loyalty.

11. Judging from the value of all the path coefficients the total effect is greater than the direct effect, namely competence of $0.297>0.217$, work discipline of $0.128>0.041$, and service quality of $0.447>0.288$. This shows that visitor satisfaction can increase the effect of employee competence, work discipline, and service quality on visitor loyalty.

12. The most dominant in influencing visitor satisfaction sequentially is the service quality variable with a path coefficient value of $0.398(28.5 \%)$, then employee discipline with a path coefficient of $0.217(14.9 \%)$ and finally employee competence with a path coefficient of $0.202(12.9 \%)$.

13. The most dominant in influencing visitor loyalty sequentially is the visitor satisfaction variable with a path coefficient of $0.400(30.9 \%)$, then service quality with a path coefficient of $0.288(21.8 \%)$, then employee competence with a path coefficient of $0.217(15.2 \%)$ and finally employee discipline with a path coefficient of $0.041(2.9 \%)$.

\section{References}

Aung, Nay, Hua Zen Ling, Adrian S. Cheng, Suneil Aggarwal, Julia Flint, Michelle Mendonca, Mohammed Rashid, Swan Kang, Susanne Weissert, and Caroline J. Coats. 2013. "Expansion of the Red Cell Distribution Width and Evolving Iron Deficiency as Predictors of Poor Outcome in Chronic Heart Failure." International Journal of Cardiology 168(3):1997-2002.

Barnes, James G. 2003. "Secrets of Customer Relationship Management (Rahasia Manajemen Hubungan Pelanggan)." Yogyakarta: Andi.

Bates, John E. G., and Douglas Hoffman. 1999. "Managing Services Marketing: Text and Readings."

Hasibuan, Malayu S. P. 2012. "Manajemen Sumber Daya Manusia Jakarta: Bumi Aksara."

Hermawati, Hermawati. 2018. "Pengaruh Kompetensi Pegawai, Kualitas Pelayanan Dan Disiplin Kerja Terhadap Kepuasan Pelanggan Pada Kantor UPT Pendapatan Wilayah Makassar 01 Selatan, Provinsi Sulawesi Selatan.” Jurnal Mirai Management 3(1):85-102.

Jasfar, Farida. 2005. Manajemen Jasa: Pendekatan Terpadu. Ghalia Indonesia.

Jasfar, Farida. 2012. "Teori Dan Aplikasi Sembilan Kunci Keberhasilan Bisnis Jasa: Sumber Daya Manusia, Inovasi, Dan Kepuasan Pelanggan.” Jakarta: Salemba Empat.

Kotler, Philip, and Gary Amstrong. 2014. "Principles of Marketin, Jilid 1 Terjemahan Bob Sabran." Jakarta: Erlangga.

Rivai, V dan Sagala, Ella Djauhari. 2013. "Manajemen Sumbert Daya Manusia Untuk Perusahaan.” Rajawali Pers, Jakarta.

Sukoco, Agus, and Sengguruh Nilowardono. 2009. “Analisa Harapan Dan Persepsi Pelanggan Atas Service Quality DiPT. PLN (Persero) APJ Surabaya Utara." Jurnal Ekonomi 9(2).

Sutrisno, Edi. 2009. "Manajemen Sumber Daya Manusia Edisi Pertama.” Jakarta: Kencana Prenada Media Group. Tjiptono, Fandy. 2000. "Manajemen Jasa." Yogyakarta: Andi Offset.

Wibowo. 2012. "Manajemen Kinerja." PT. Raja Grafindo Persada.

Wibowo. 2014. "Manajemen Kinerja.” Kinerja, Edisi Keempat, Jakarta : Rajawali Pers. 